\title{
Evaluation of tissue trauma and healing on the basis of tumour necrosis factor-alpha, interleukin-6 and C-reactive protein in peripheral blood during and after pyometra in bitches
}

\author{
TUĞBA SEVAL FATMA TOYDEMIR KARABULUT, KIVILCIM SÖNMEZ*
}

\author{
Department of Gynaecology and Obstetrics, *Department of Pathology, \\ Faculty of Veterinary Medicine, Istanbul University, Avcılar Campus, Istanbul, 34320, Turkey
}

Toydemir Karabulut T. S. F., Sönmez K.

Evaluation of tissue trauma and healing on the basis of tumour necrosis factor-alpha, interleukin-6 and C-reactive protein in peripheral blood during and after pyometra in bitches

\section{Summary}

In this study, inflammation in the blood of bitches with pyometra (PG) was compared before and 15 days after ovariohysterectomy (OVH). The results were compared with those for control dioestrus bitches (CG) to reveal the evidence of inflammation in blood after a routine surgery. Inflammation was tracked by tumour necrosis factor-alpha (TNF- $\alpha$ ), interleukine-6 (IL-6) and C-reactive protein (CRP), using immunocytochemistry (ICC) and immunofluorescence capture of blood cells in cell blocks. ICC is performed mainly during routine cytological examinations, whereas the use of cell blocks in blood examination is uncommon. Insofar as we know, this is the first study using cell block techniques on canine blood samples. Three commercially available antibodies against TNF- $\alpha$, IL-6 and CRP, forming two panels, were evaluated. A standard streptoavidin-biotin complex technique was used for ICC. TNF- $\alpha$ and IL-6 labelling was scored for colour and intensity, and CRP for immunofluorescence capture. TNF- $\alpha$ and IL-6 colour and intensity scores differed significantly between the PG and CG groups, and were higher in PG before $\mathrm{OVH}(\mathrm{P}<0.01, \mathrm{P}<0.01, \mathrm{P}<0.001, \mathrm{P}<0.01$, respectively). IL-6 intensity was significantly greater in PG 15 days after OVH $(P<0.05)$. CRP capture in PG was strong before $\mathrm{OVH}$ and high in both groups 15 days later. Low-dose anti-inflammatory agents or an anti-cytokine therapy may be useful in pyometra treatment in the future because these treatments may offer protection from systemic inflammatory response syndrome before and after $\mathrm{OVH}$.

Keywords: female dog, inflammation, anti-cytokine therapy, SIRS

Pyometra is the accumulation of pus in the uterus. Bacterial colonization of the uterus can lead to systemic inflammation that threatens life (7). In an intact bitch, repeated cycles of oestrogen and progesterone stimulation can result in endometrial pathology (8). Cystic endometrial hyperplasia can support bacterial growth, and a secondary colonization by Escherichia coli provides the primary opportunistic pathogen (11). $E$. coli originating from faeces can enter by the vaginal route as an ascending infection. Canines are especially susceptible in the luteal phase of their estrous cycle. Hematogenous or lymphatic sources are also possible (8).

Complications of $E$. coli-associated pyometra can include serious-to-fatal sepsis and endotoxemia. The endotoxin of $E$. coli is a very potent inflammatory stimulant; it is a lipopolysaccharide (LPS) that activates blood platelets and may cause hypercoagulation (disseminated intravascular coagulation, or DIC) (13). The host immune response includes leukocyte release of pro-inflammatory cytokines, such as interleukin-6 (IL-6), IL-8 and tumour necrosis factor-alpha (TNF- $\alpha$ ) $(4,13,16)$. Cytokines, especially IL-6, trigger production of acute-phase proteins (APP) $(6,11)$, such as C-reactive protein (CRP), which is synthesized in the liver and may be useful as an inflammatory indicator in blood (5). CRP binds to the surface of dead cells and promotes phagocytosis (9). In an intensive care unit (ICU), inflammation is tracked mainly by detection of TNF- $\alpha$, IL-6 and CRP in circulation (25). TNF- $\alpha$ has 
a very short half-life in circulation, and is elevated in blood during the acute phase of inflammation $(3,18)$. Interleukin-6 is a prognostic marker in dogs, with high blood levels indicating poor prognosis (25). CRP has been found to be a good indicator for an ongoing systemic inflammatory response syndrome (SIRS) during pyometra (7).

Cytokines induce a normal immune response. However, dysregulated cytokine signalling associated with LPS and/or sepsis can result in autoimmunity (6), cytokine storm, SIRS, septic shock, multiple organ dysfunction syndrome (MODS) and death (1, 4, 13, 27). The duration of SIRS also determines the risk of developing MODS (14).

The aims of this study were 1) to evaluate TNF- $\alpha$, IL-6 and CRP in bitches with pyometra before and during the recovery period following ovariohysterectomy $(\mathrm{OVH})$ and to compare the results with those from healthy dioestrus bitches that underwent elective $\mathrm{OVH} ; 2$ ) to determine whether OVH would increase blood inflammatory markers in pyometra-affected and healthy bitches; and 3) to evaluate the „cell blocks” method for efficacy in blood preservation, which, in turn, facilitates determining TNF- $\alpha$, IL-6 and CRP.

\section{Material and methods}

Dogs. Dogs enrolled in this study were patients of the Faculty of Veterinary Medicine at Istanbul University. This randomized trial included two groups of bitches: one group with pyometra (PG; $n=21)$ and a control group of healthy dioestrus bitches (CG; $n=5)$. The mean ages of the dogs at the start of the study were $7.9 \pm 0.57$ years for PG and $5.7 \pm 1.36$ years for CG. According to a five-point body condition scoring system, the mean body condition scores were $3.05 \pm 0.16$ for PG and $3.40 \pm 0.24$ for CG. Vaginoscopy and ultrasonography (Easote Pie Medical MyLab Five Vet, Netherlands) were used to assess the uterus of study subjects. Fluid in the uterus presents as anechoic or hypoechoic ultrasonography, which may reflect pyometra, hydrometra, or mucometra. Clinical signs, vaginal cytology, clinical chemistry and patient history can support a differential diagnosis. OVHs were performed on the day of arrival. Seventeen (PG) bitches had pyometra with an open cervix, and four had pyometra with a closed cervix (\#P5, \#P9, \#P13, \#P16). Bitches in CG had no known diseases and had applied only for OVH. A broad-spectrum antibiotic therapy (ceftriaxone or enrofloxacin) was given to all bitches in PG and CG after OVHs. There was no specific grouping for antibiotic selection in the study. Ceftriaxone was administered to 7 bitches in the PG and 1 bitch in CG, whereas enrofloxacin was given to 14 animals in PG and to 4 in CG. Owner permission for study participation was obtained before blood samples were collected. The study was approved by the Istanbul University Ethics Committee (\#1702011).

Sampling procedures. Blood was taken aseptically from a vena cephalica antebrachii or a vena saphena parva; $1 \mathrm{~mL}$ of blood was collected into polystyrene tubes that contained
$1 \mathrm{~mL}$ of $7.5 \%$ buffered formaline (Histologic Grade Formaldehyde; Sigma-Aldrich). The tubes were capped tightly and gently shaken by hand for mixture.

Blood was also collected into EDTA tubes to determine the complete blood cell count (CBC). Specimens were analyzed using a ProCyte Dx HematologyAnalyzer (Idexx, USA) at our hospital laboratory. The bitches in both groups were sampled twice, on admission to the hospital (before $\mathrm{OVH})$ and 15 days later.

Cell blocks. Cell blocks were prepared according to Kung et al. (15). Blood samples were fixed and incubated at room temperature for 4-6 hours, and then cell pellets were embedded in 2\% bacteriological agar in Eppendorf tubes and left at room temperature for cooling. Embedded cell blocks were wrapped in filter paper and processed routinely as tissue specimens. Sections of 3-4 $\mu$ m were cut from cell blocks with a rotary microtome. One section of each specimen was stained with haematoxylin and eosin (H\&E) to observe cell morphology, while three sections were placed on positive-charged adhesion microscope slides (Citoglass, Citotest Labware Manufacturing Co. Ltd.) and reserved for immunocytochemistry (ICC). Blood smears were also prepared to compare cell morphology between H\&E slides and cell blocks. For this purpose, slides were prepared and air-dried for $5 \mathrm{~min}$ before staining. Smears were stained with May-Grünwald-Giemsa azur methylene blue solution stain (MGG; Merck KGaA, Darmstadt, Germany) and rinsed with deionized water and air dried before evaluation.

Immunocytochemical detection of TNF- $\alpha$ and IL-6. Slides of cell blocks were deparaffinized, followed by antigen retrieval and the endogen peroxidise and protein blocking procedures. The slides were incubated with antibody to TNF- $\alpha$ (diluted $1: 150 ; 1.5 \mathrm{~h}$, room temperature, R\&D Systems, Cat. no: MAB1507) and IL-6 (diluted $1: 200$; $1.5 \mathrm{~h}$, room temperature, R\&D Systems, Cat. no: AF1609) and then treated with a commercial secondary antibody kit (Invitrogen, Histostain-Plus IHC Kit, HRP, broad spectrum, Cat. No: 85-9043, Paisley, UK). These steps were followed by marking with 3,3'-Diaminobenzidine (DAB) chromogen (Invitrogen, DAB-Plus Substrate Kit, Cat. No: 00-2020, Paisley, UK). Lastly, the sections were counterstained with Mayer's haematoxylin. Negative control sections were incubated with antibody diluent instead of the primary antibody. Antigen retrieval was performed using citrate buffer solution.

Immunofluorescence capture of CRP. Direct immunofluorescence labelling of CRP from cell blocks was performed according to Mera et al. (20). The slide sections were dried overnight at $37^{\circ} \mathrm{C}$. The slides were de-waxed, rehydrated, washed in Tris-saline buffer ( $\mathrm{pH} 7.8$ ), and trypsinised for $40 \mathrm{~min}$ at $37^{\circ} \mathrm{C}$ in a solution of $0.1 \%$ calcium chloride and $0.05 \%$ trypsin. The slides were washed again with Tris-saline buffer ( $\mathrm{pH} 7.8$ ) and incubated in a moist chamber for $30 \mathrm{~min}$ with commercially available fluorescein conjugates of rabbit anti-canine $\mathrm{C}$-reactive protein $\mathrm{Ab}$ (diluted 1: 1000; $20 \mathrm{~min}$, room temperature, Assaypro; RPE-Canine C-Reactive Protein Ab, Cat. no: 11922-05051, USA). The slides were washed three times with phosphate 
buffered saline (PBS; pH 7.4, 0.1 M, Sigma-Aldrich, Germany) before being mounted (Dako, fluorescent mounting medium, USA).

Evaluation of TNF- $\alpha$, IL-6 and CRP. The slides were examined using an Olympus BX50 light microscope and the Olympus DP2-BSW software program. Scoring for evaluation of TNF- $\alpha$ and IL- 6 was based on ICC staining colour and intensity. The results were graded from 0 to $+++(0-$ no staining; + - weak staining; ++ - moderate staining; +++ - intense staining). Five areas on each slide were selected randomly for this purpose, and the percentage of cells with various staining intensities was determined (2). The slides were examined under a $100 \times$ objective with immersion oil.
CRP expression was determined using an Olympus microscope equipped with FITC exciter and barrier filters, with incident illumination from an Olympus U-LH100HG $100 \mathrm{~W}$ light source. The staining of the slides was scored according to fluorescence intensity as $0-$ no capture, +- weak capture, ++- moderate capture or +++- intense capture. Evaluation was done under a $100 \times$ objectives with immersion oil.

The ICC sections were evaluated by two observers blinded to the clinical status of the bitches.

Statistical analyses. Descriptive statistics and repeated ANOVA tests were applied to $\mathrm{CBC}$ and ICC results for TNF- $\alpha$ and IL-6. An independent sample t-test was applied to compare each sampling time. Group, sampling time, and sampling time $\times$ group interaction were included in the models. A paired $t$-test was used to compare values between days 0 and 15 . For interpretation of ICC results, the scores of 0 to +++ were numbered as 1 to 4 . A value of $\mathrm{P}<0.05$ was determined as an indicator of statistical significance.

\section{Results and discussion}

Prior to $\mathrm{OVH}$, the mean body temperature was 38.66 $\pm 0.16^{\circ} \mathrm{C}$ in $\mathrm{PG}$ and $38.2 \pm 0.08^{\circ} \mathrm{C}$ in $\mathrm{CG}(\mathrm{P}>0.05)$. At surgery, none of the bitches were diagnosed with peritonitis. Fifteen days after surgery, all bitches in both groups had good appetite, with no surgery site inflammation or other health problems.

The mean and standard error values for $\mathrm{CBC}$ comparisons are presented in Table 1. In PG, WBCs were lower and PLT levels were higher 15 days after OVH $(\mathrm{P}<0.01)$. MCHC was lower in both groups after 15 days $(\mathrm{P}<0.05$ in $\mathrm{CG} ; \mathrm{P}<0.001$ in $\mathrm{PG})$.
Tab. 1. CBC results in CG and PG before $\mathrm{OVH}$ and 15 days after $\mathrm{OVH}$

\begin{tabular}{|c|c|c|c|c|c|}
\hline \multirow{2}{*}{ Variable } & \multirow{2}{*}{$\begin{array}{c}\text { Control }(n=5) \\
\text { Mean } \pm \text { SE }\end{array}$} & \multirow{2}{*}{$\begin{array}{c}\text { Pyometra }(n=21) \\
\text { Mean } \pm \text { SE }\end{array}$} & \multicolumn{3}{|c|}{ Repeated ANOVA } \\
\hline & & & Group & $\mathbf{T}$ & $G \times T$ \\
\hline $\mathrm{RBC} 0^{\text {th }}$ day $\left(\times 10^{6} \mu \mathrm{L}\right)$ & $6.24 \pm 0.68^{\mathrm{a}, \mathrm{A}}$ & $5.80 \pm 0.21^{\mathrm{a}, \mathrm{A}}$ & \multirow{2}{*}{ NS } & \multirow{2}{*}{ NS } & \multirow{2}{*}{ NS } \\
\hline RBC $15^{\text {th }}$ day $\left(\times 10^{6} \mu \mathrm{L}\right)$ & $6.00 \pm 0.74^{\mathrm{a}, \mathrm{A}}$ & $5.54 \pm 0.24^{\mathrm{a}, \mathrm{A}}$ & & & \\
\hline WBC $0^{\text {th }}$ day $\left(\times 10^{3} \mu \mathrm{L}\right)$ & $16.09 \pm 2.20^{\mathrm{a}, \mathrm{A}}$ & $38.92 \pm 6.20^{\mathrm{a}, \mathrm{A}}$ & \multirow{2}{*}{ NS } & \multirow{2}{*}{ NS } & \multirow{2}{*}{ NS } \\
\hline WBC $15^{\text {th }}$ day $\left(\times 10^{3} \mu L\right)$ & $13.52 \pm 1.85^{\mathrm{a}, \mathrm{A}}$ & $18.46 \pm 2.61^{a, c}$ & & & \\
\hline HCT $0^{\text {th }}$ day (\%) & $45.2 \pm 3.85^{\mathrm{a}, \mathrm{A}}$ & $38.95 \pm 1.38^{\mathrm{a}, \mathrm{A}}$ & \multirow{2}{*}{ NS } & \multirow{2}{*}{ NS } & \multirow{2}{*}{ NS } \\
\hline HCT $15^{\text {th }}$ day (\%) & $44 \pm 4.60^{\mathrm{a}, \mathrm{A}}$ & $37.86 \pm 1.58^{\mathrm{a}, \mathrm{A}}$ & & & \\
\hline HGB $0^{\text {th }}$ day $(\mathrm{g} / \mathrm{dL})$ & $14.70 \pm 1.46^{\mathrm{a}, \mathrm{A}}$ & $12.87 \pm 0.42^{\mathrm{a}, \mathrm{A}}$ & \multirow{2}{*}{ NS } & \multirow{2}{*}{ NS } & \multirow{2}{*}{ NS } \\
\hline HGB $15^{\text {th }}$ day $(\mathrm{g} / \mathrm{dL})$ & $14.08 \pm 1.60^{\mathrm{a}, \mathrm{A}}$ & $12.36 \pm 0.55^{\mathrm{a}, \mathrm{A}}$ & & & \\
\hline PLT $0^{\text {th }}$ day $\left(\times 10^{3} \mu \mathrm{L}\right)$ & $524 \pm 97.57^{\mathrm{a}, \mathrm{A}}$ & $285.05 \pm 35.95^{\mathrm{b}, \mathrm{A}}$ & NS & NS & NS \\
\hline PLT $15^{\text {th }}$ day $\left(\times 10^{3} \mu \mathrm{L}\right)$ & $488.8 \pm 107.74^{\mathrm{a}, \mathrm{A}}$ & $450.05 \pm 63.76^{a, c}$ & & & \\
\hline MCV $0^{\text {th }}$ day $\mathrm{fl}$ & $72.8 \pm 2.35^{\mathrm{a}, \mathrm{A}}$ & $67.29 \pm 0.67^{c, A}$ & \multirow[t]{2}{*}{$\star$} & \multirow{2}{*}{ NS } & \multirow{2}{*}{ NS } \\
\hline MCV $15^{\text {th }}$ day fl & $73 \pm 2.77^{\mathrm{a}, \mathrm{A}}$ & $67.43 \pm 1.60^{\mathrm{a}, \mathrm{A}}$ & & & \\
\hline MCH $0^{\text {th }}$ day (pg) & $23.8 \pm 0.37^{\mathrm{a}, \mathrm{A}}$ & $22.05 \pm 0.25^{c, c}$ & \multirow{2}{*}{ ** } & \multirow{2}{*}{ NS } & \multirow{2}{*}{ NS } \\
\hline MCH $15^{\text {th }}$ day $(\mathrm{pg})$ & $23.4 \pm 0.4^{\mathrm{a}, \mathrm{A}}$ & $21.67 \pm 0.25^{c, A}$ & & & \\
\hline MCHC $0^{\text {th }}$ day (\%) & $32.40 \pm 0.51^{\mathrm{a}, \mathrm{B}}$ & $32.86 \pm 0.28^{\mathrm{a}, \mathrm{A}}$ & \multirow{2}{*}{ NS } & \multirow{2}{*}{ ** } & \multirow{2}{*}{ NS } \\
\hline MCHC $15^{\text {th }}$ day $(\%)$ & $31.60 \pm 0.51^{\mathrm{a}, \mathrm{B}}$ & $31.67 \pm 0.29 \mathrm{a}, \mathrm{C}$ & & & \\
\hline
\end{tabular}

Explanations: $\mathrm{T}-$ sampling time; $\mathrm{G} \times \mathrm{T}-$ group $\times$ sampling time interaction; $\mathrm{a}, \mathrm{b}$, $\mathrm{c}$ - means with different superscript letters differ significantly in the same row; A, B, $\mathrm{C}-$ means with different superscript letters differ significantly in the same column; a, $\mathrm{A}-\mathrm{P}<0.05 ;{ }^{\mathrm{b}, \mathrm{B}}-\mathrm{P}<0.01 ;{ }^{\mathrm{c}, \mathrm{C}}-\mathrm{P}<0.001 ; \mathrm{NS}-\mathrm{P}>0.05$

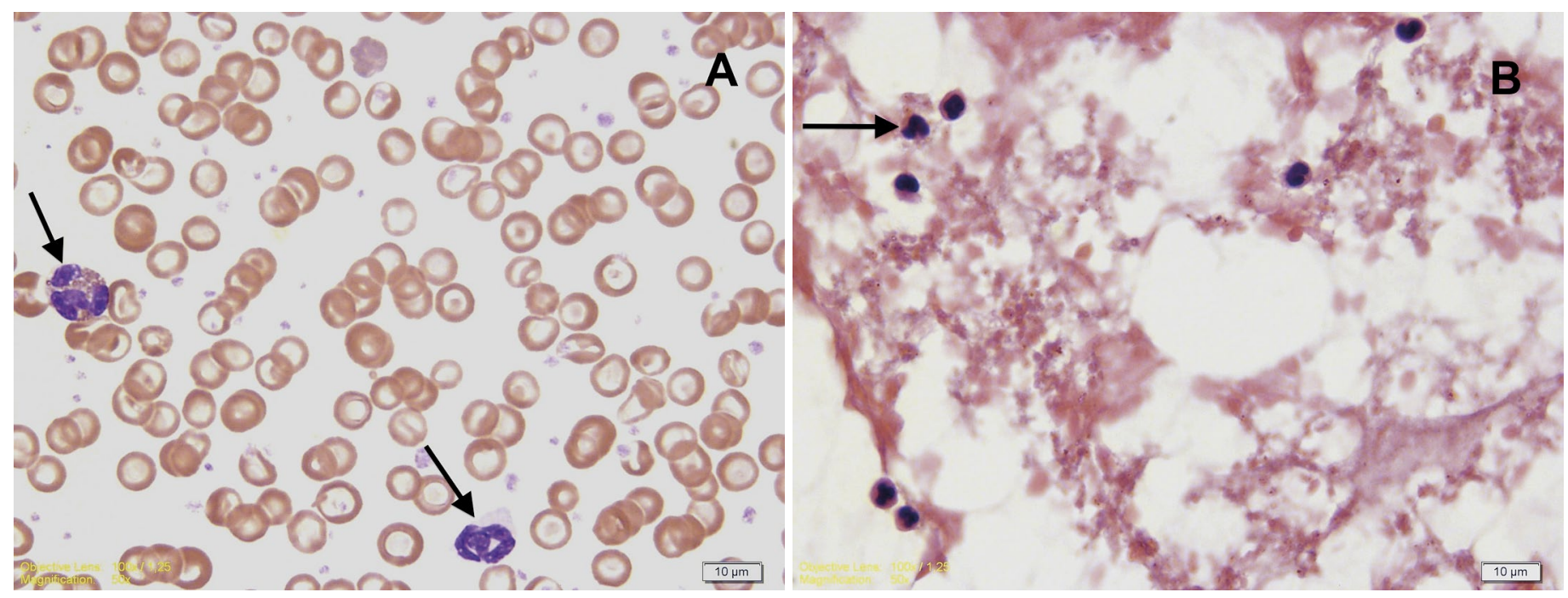

Fig. 1. Appearance of blood cells: (A) Blood smear. Leukocytes (black arrow). MGG. (B) "Cell blocks" of blood. Leukocytes (black arrow). H\&E 
Cell morphology on blood smears vs. cell blocks. Erythrocytes and leukocytes appeared larger and clearer than cells from cell block sections (Fig. 1A). In the case of specimens from cell blocks, erythrocytes were visible, but their shapes, borders and cytoplasm were less obvious, especially with larger numbers of cells in examination areas. Platelets were not apparent on slides from cell blocks (Fig. 1B). Clumps of bacteria were observed on cell block slides from some bitches with pyometra before $\mathrm{OVH}$.

Comparison of TNF- $\alpha$, IL-6 and CRP labelling between PG and CG. The means and standard errors for TNF- $\alpha$ and IL- 6 are presented in Table 2 . TNF- $\alpha$ colour and intensity scores were higher in $\mathrm{PG}$ at day $0(\mathrm{P}<0.01)$. IL-6 colour and intensity scores were higher in $\mathrm{PG}$ at day $0(\mathrm{P}<0.001, \mathrm{P}<0.01)$, and IL-6 intensity remained significantly greater, compared with $\mathrm{CG}$, at day $15(\mathrm{P}<0.05)$. Strong or moderate labelling of TNF- $\alpha$ and IL- 6 was seen in all bitches before OVH in PG (Fig. 2A, B and Fig. 3A, B, respectively). Although most of the samples were positive for TNF- $\alpha$ and IL-6 labelling after 15 days, negative
Tab. 2. TNF- $\alpha$ and IL-6 labelling in cell blocks: colour and intensity scores before OVH and 15 days after $\mathrm{OVH}$

\begin{tabular}{|c|c|c|c|c|c|}
\hline \multirow{2}{*}{ Variable } & \multirow{2}{*}{$\begin{array}{c}\text { Control }(n=5) \\
\text { Mean } \pm \text { SE }\end{array}$} & \multirow{2}{*}{$\begin{array}{c}\text { Pyometra }(n=21) \\
\text { Mean } \pm \text { SE }\end{array}$} & \multicolumn{3}{|c|}{ Repeated ANOVA } \\
\hline & & & Group & $T$ & $G \times T$ \\
\hline TNF- $\alpha$ colour $0^{\text {th }}$ day & $1.6 \pm 0.24^{\mathrm{a}, \mathrm{A}}$ & $2.76 \pm 0.17^{\mathrm{c}, \mathrm{A}}$ & \multirow{2}{*}{ * } & \multirow{2}{*}{ ** } & \multirow{2}{*}{ * } \\
\hline TNF- $\alpha$ colour $15^{\text {th }}$ day & $2.4 \pm 0.40^{\mathrm{a}, \mathrm{A}}$ & $2.86 \pm 0.16^{a, A}$ & & & \\
\hline TNF- $\alpha$ intensity $0^{\text {th }}$ day & $2.0 \pm 0.55^{\mathrm{a}, \mathrm{A}}$ & $3.38 \pm 0.18^{\mathrm{b}, \mathrm{A}}$ & * & NS & NS \\
\hline TNF- $\alpha$ intensity $15^{\text {th }}$ day & $2.4 \pm 0.51^{\mathrm{a}, \mathrm{A}}$ & $3.10 \pm 0.18^{\mathrm{a}, \mathrm{A}}$ & & & \\
\hline IL-6 colour $0^{\text {th }}$ day & $1.4 \pm 0.24^{\mathrm{a}, \mathrm{A}}$ & $2.71 \pm 0.14^{c, A}$ & \multirow{2}{*}{ ** } & \multirow{2}{*}{ NS } & \multirow{2}{*}{ NS } \\
\hline IL-6 colour $15^{\text {th }}$ day & $1.8 \pm 0.37^{\mathrm{a}, \mathrm{A}}$ & $2.57 \pm 0.16^{\mathrm{a}, \mathrm{A}}$ & & & \\
\hline IL-6 intensity $0^{\text {th }}$ day & $1.4 \pm 0.24^{\mathrm{a}, \mathrm{A}}$ & $2.71 \pm 0.17^{\mathrm{b}, \mathrm{A}}$ & \multirow{2}{*}{ ** } & \multirow{2}{*}{ NS } & \multirow{2}{*}{ NS } \\
\hline IL-6 intensity $15^{\text {th }}$ day & $1.6 \pm 0.24^{\mathrm{a}, \mathrm{A}}$ & $2.62 \pm 0.18^{\mathrm{b}, \mathrm{A}}$ & & & \\
\hline
\end{tabular}

Explanations: TNF- $\alpha$ - tumournecrosis factor alpha; IL-6 - interleukine-6; T - sampling time; $\mathrm{G} \times \mathrm{T}-$ group $\times$ sampling time interaction; $\mathrm{a}, \mathrm{b}, \mathrm{c}-$ means with different superscript letters differ significantly in the same row; $\mathrm{A}, \mathrm{B}, \mathrm{C}$ - means with different superscript letters differ significantly in the same column; ${ }^{\mathrm{a}, \mathrm{A}}-\mathrm{P}<0.05$; ${ }^{\mathrm{b}, \mathrm{B}}-\mathrm{P}<0.01$; C $-\mathrm{P}<0.001 ; \mathrm{NS}-\mathrm{P}>0.05$

TNF- $\alpha$ and IL-6 labelling was seen in some PG bitches (Fig. 2C and Fig. 3C, respectively). Positive labelling of TNF- $\alpha$ and IL-6 antigen was seen in leukocytes before $\mathrm{OVH}$ in some $\mathrm{PG}$ bitches that showed a strong diffuse labelling of these antigens in serum at day 15 (Fig. 4A, B).

CRP capturing was present with different intensities $(++,+++)$ before OVH in all PG samples. Only three bitches in CG showed no CRP capturing (-), while in
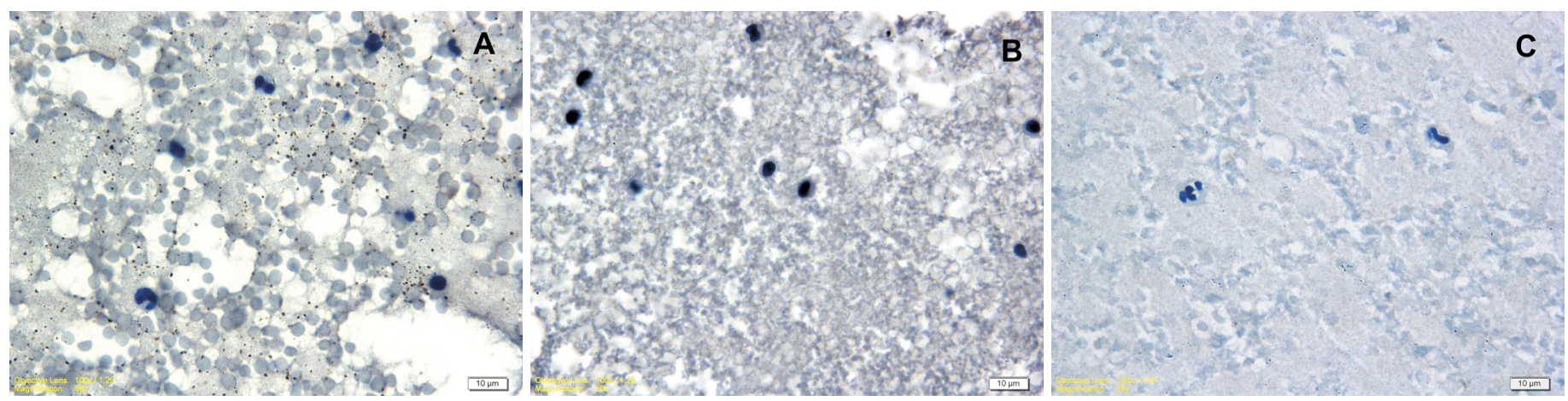

Fig. 2. (A) Strong labelling of TNF- $\alpha$ antigen in blood (+++, +++; \#P14, before OVH). ICC. (B) Moderate labelling of TNF- $\alpha$ antigen in blood $(+,++$; \#P3, before OVH). ICC. (C) Negative labelling of TNF- $\alpha$ antigen in blood (-, -; \#P1, 15 days after OVH). ICC. All slides from cell blocks

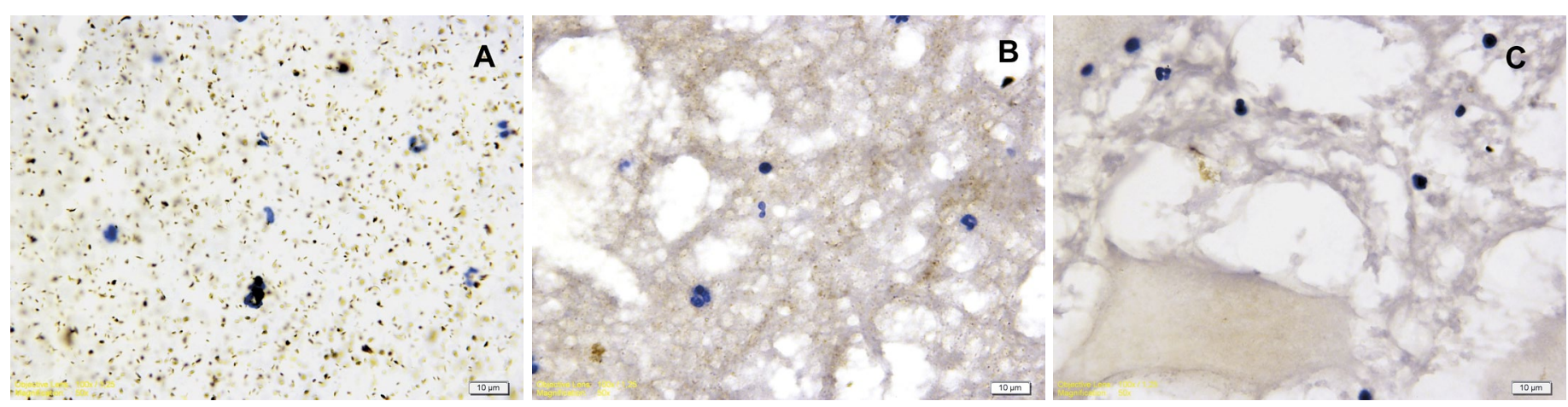

Fig. 3. (A) Strong labelling of IL-6 antigen in blood (+++, +++; \#P14, before OVH). ICC. (B) Moderate but diffuse labelling of IL-6 antigen in blood (+, ++; \#C3, 15 days after OVH). ICC. (C) Negative labelling of IL-6 antigen in blood (-, -; \#P1, 15 days after OVH). ICC. All slides from cell blocks 
two others the intensity of CRP capturing was weak $(+)$. All bitches in both groups showed strong CRP capturing at day $15(+++)$ (Fig. 5).

In this study, CBC results, TNF- $\alpha$ and IL- 6 antigen expressions and CRP capture were compared before and 15 days after $\mathrm{OVH}$ in bitches with pyometra and bitches in normal dioestrus. WBCs in PG were greater before OVH than they were 15 days later $(\mathrm{P}<0.01)$. The change could have also been a physiological response to lower stress during the second examination.

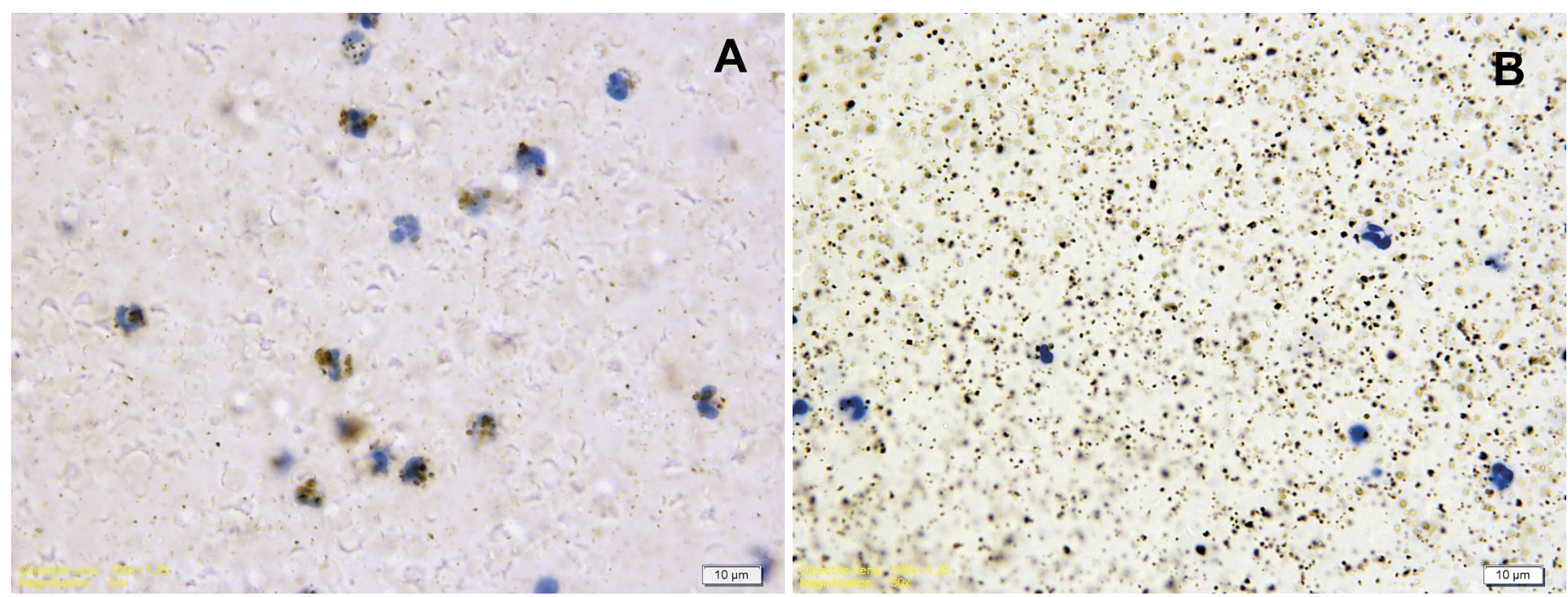

Fig. 4. (A) Positive labelling of TNF- $\alpha$ antigen inside leukocytes (++, ++; \#P19, before OVH). ICC. (B) Strong and diffuse labelling of TNF- $\alpha$ antigen (+++, +++; \#P19, 15 days after OVH). ICC. All slides from cell blocks
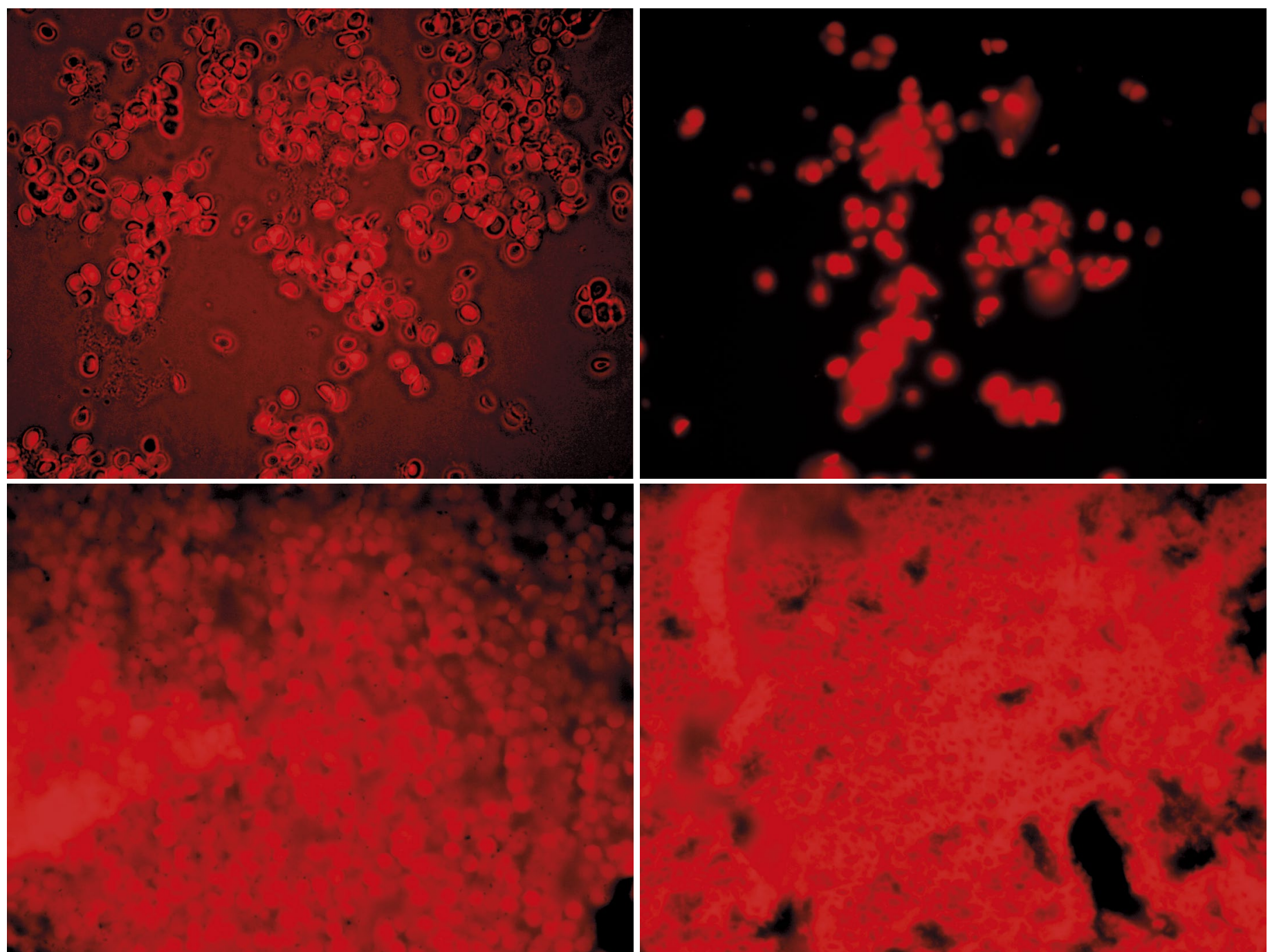

Fig. 5. Fluorescence images of red blood cells capturing CRP: low intensity (left side), high intensity (right side). (Top images show few cells; bottom images show diffuse cells with serum capturing CRP). All slides from cell blocks 
PLT levels in PG were lower before $\mathrm{OVH}$, returning to normal levels 15 days after OVH. A low level of PLT has been described in bitches with pyometra (24) and is seen in other acute infections. The presence of DIC may increase the risk of haemorrhage (23). CBC results in our study were in accordance with previous studies $(8,23,24)$.

In another study by Maciel et al. (18), there was no difference in TNF- $\alpha$ levels between dioestrus and pyometra bitches before OVH, In our study, on the other hand, TNF- $\alpha$ and IL-6 labelling as well as CRP capture in cell blocks were higher in $\mathrm{PG}$ compared with CG prior to $\mathrm{OVH}$, and they were still higher in most PG bitches 15 days afterwards. Only one bitch in PG responded well to antibiotic therapy and $\mathrm{OVH}$, and she had a negative labelling of TNF- $\alpha$ and IL- 6 after 15 days. There was no difference between the effects of the antibiotics used (ceftriaxone and enrofloxacin) on TNF- $\alpha$ and IL-6 labelling or on CRP capture in our study. Fifteen days after OVH in PG, eighteen bitches still showed strong positive labelling $(++,+++)$ for TNF- $\alpha$ and thirteen bitches for IL-6.

Expressions of TNF- $\alpha$ and IL-6 increased in CG after OVH ( $\mathrm{P}>0.05)$. After 15 days, all bitches in both groups showed a higher intensity of CRP capture.

Routinely, TNF- $\alpha$, IL- 6 , and CRP in serum are detected by enzyme-linked immunosorbent assay (ELISA). In our study, immunocytochemistry (ICC) and immunofluorescence tests were tried on cell blocks. Cell block techniques are used infrequently to preserve blood cells. Cell blocks have gained importance in routine cytopathology, and there are many methods of preparation $(10,21)$. In our study, agar embedding was chosen. As described by Jain et al. (10), heat-related artefacts were observed in cell morphology. Thus, it is not advisable to use cell block techniques if morphology of cells at the histological level is important; also, atypia are difficult to recognize. However, repetitive use of the same blood sample with this method made it possible to identify cytokine expression in peripheral blood.

Reproductive infections and trauma can cause sepsis in dogs (22), and pyometra can be associated with DIC, SIRS, septic shock and MODS. The safest and most effective treatment for pyometra is $\mathrm{OVH}$ (12), although surgery is also associated with various degrees of inflammation. Thus, corticosteroids, antiinflammatory agents, anti-endotoxine antibodies and anti-cytokine therapies have been evaluated in humans and some animal species $(17,19,26,28)$. According to our results, it would be beneficial to develop a cytokine- or toxin-targeting drug to support treatment of canine pyometra.

In conclusion, it is thought that TNF- $\alpha$, IL- 6 , and CRP evaluations in blood are very useful for scientists and clinicians to track inflammation in circulation.
TNF- $\alpha$ and IL- 6 antigen expressions, as well as CRP capture, were observed before and 15 days after $\mathrm{OVH}$, mostly in PG. CRP capture was also noted in some CG bitches.

\section{References}

1.Bar-Or D., Carrick M. M., Mains C. W., Rael L. T., Slone D., Brody E. N.: Sepsis, oxidative stress, and hypoxia: Are there clues to better treatment? Redox Report 2015, 20, 193-197, doi: 10.1179/ 1351000215Y.0000000005.

2.Bilous M., Dowsett M., Hanna W., Isola J., Lebeau A., Moreno A., PenaultLlorca F., Rüschoff J., Tomasic G., Vijver M. van de: Current perspectives on HER2 testing: A review of national testing guidelines. Modern Pathology 2003, 16, 173-182, doi: 10.1097/ 01.MP.0000052102.90815.82.

3. Birks E. J., Owen V. J., Burton P. B. J., Bishop A. E., Banner N. R., Khaghani A., Polak J. M., Yacoub M. H.: Tumor Necrosis Factor- $\alpha$ Is Expressed in Donor Heart and Predicts Right Ventricular Failure After Human Heart Transplantation. Circulation 2000, 102, 326-331, doi: 10.1161/01.CIR.102.3.326.

4. Cavaillon J.-M., Annane D.: Compartmentalization of the inflammatory response in sepsis and SIRS. J. Endotoxin Res. 2006, 12, doi: 10.1179/ 096805106 X102246.

5. Ceron J. J., Eckersall P. D., Silvia Martinez-Subiela S.: Acute phase proteins in dogs and cats: current knowledge and future perspectives. Vet. Clin. Pathol. 2005, 34, 85-99.

6.Drutskaya M. S., Efimov G. A., Astrakhantseva I. V., Kruglov A. A., Nedospasov $S$. A.: Making anti-cytokine therapy more selective: Studies in mice. Cytokine 2018, 101, 33-38.

7. Fransson B. A., Lagerstedt A.-S., Bergstrom A., Hagman R., Park J. S., Chew B. P., Evans M. A., Ragle C. A.: C-reactive protein, tumor necrosis factor a, and interleukin-6 in dogs with pyometra and SIRS. J. Vet. Emerg. Crit. Care 2007, 17, 373-381, doi: 10.1111/j.1476 - 4431.2006.00203.x.

8. Hagman R.: Clinical and Molecular Characteristics of Pyometra in Female Dogs. Reprod. Dom. Anim. 2012, 47, 323-325, doi: 10.1111/rda.12031 ISSN 0936-6768.

9. Hwang J., Seo Y., Jo Y., Son J., Choi J.: Aptamer-conjugated live human immune cell based biosensors for the accurate detection of C-reactive protein. Sci. Rep. 2016, 6, 34778, doi: 10.1038/srep34778.

10. Jain D., Mathur S. R., Iyer V. K.: Cell blocks in cytopathology: a review of preparative methods, utility in diagnosis and role in ancillary studies. Cytopathology 2014, 25, 356-371, doi: 10.1111/cyt.12174.

11. Jitpean S., Holst B. S., Höglund O. V., Pettersson A., Strage E. O., Södersten F., Hagman R.: Serum insulin-like growth factor-I, iron, C-reactive protein, and serum amyloid A for prediction of outcome in dogs with pyometra. Theriogenology 2014, 82, 43-48, doi: 10.1016/j.theriogenology.2014.02.014.

12.Jitpean S., Ström-Holst B., Emanuelson U., Höglund O. V., Pettersson A., Alneryd-Bull C., Hagman R.: Outcome of pyometra in female dogs and predictors of peritonitis and prolonged postoperative hospitalization in surgically treated cases. BMC Vet. Res. 2014, 10, 6, http://www.biomedcentral. com/1746-6148/10/6.

13. Kell D. B., Pretorius E.: To what extent are the terminal stages of sepsis, septic shock, SIRS, and multiple organ dysfunction syndrome actually driven by a prion/amyloid form of fibrin? bioRxiv preprint, 2016, doi: 10.1101/057851.

14.Konończuk T., Lukaszuk B., Żendzian-Piotrowska M., Dabrowski A., Krzyżak M., Ostrowska L., Kurek K.: Plasma Sphingolipids in Acute Pancreatitis. Inter. J. Mol. Sci. 2017, 18, 2606, doi: 10.3390/ijms18122606.

15. Kung I. T., Chan S. K., Lo E. S.: Application of the immunoperoxidase technique to cell block preparations from fine needle aspirates. Acta Cytolog. 1990, 34, 297-303.

16. Liu S. J., Shi Y., Liu C., Zhang, M., Zuo Z., Zeng C. J., Zhou G. B., Xian H., Song T. $Z$.: The upregulation of pro-inflammatory cytokines in the rabbit uterus under the lipopolysaccaride-induced reversible immunoresponse state. Anim. Reprod. Sci. 2017, 176, 70-77, doi: 10.1016/j.anireprosci.2016.11.012.

17. Liua Z., Fanc Y., Wanga Y., Hana C., Panb Y., Huang H., Yeb Y., Luob L., Yina $Z$.: Dipyrithione inhibits lipopolysaccharide-induced iNOS and COX-2 up-regulation in macrophages and protects against endotoxic shock in mice. FEBS Letters 2008, 582, 1643-1650, doi: 10.1016/j.febslet.2008.04.016.

18. Maciel G. S., Uscategui R. R., Almeida V. T. de, Oliveira M. E. F., Feliciano M. A. R., Vicente W. R. R.: Quantity of IL-2, IL-4, IL-10, INF-c, TNF-a and $\mathrm{KC}$-Like Cytokines in Serum of Bitches With Pyometra in Different Stages of Oestrous Cycle and Pregnancy. Reprod. Dom. Anim. 2014, 49, 701-704, doi: 10.1111/rda.12360.

19. Martin E. M., Messenger K. M., Sheats M. K., Jones S. L.: Misoprostol inhibits lipopolysaccharide-induced pro-inflammatory cytokine production by equine leucocytes. Front. Vet. Sci. 2017, 4, 160, doi: 10.3389/fvets. 2017.00160. 
20. Mera S. L., Young E. W., Bradfield J. W. B.: Direct immunofluorescence of skin using formalin-fixed paraffin embedded sections. J. Clin. Pathol. 1980, 33, 365-369.

21. Nathan N. A., Narayan E., Smith M. M., Horn M. J.: Improved Preparation and Its Efficacy in Diagnostic Cytology. Am. J. Clin. Pathol. 2000, 114, 599-606.

22. Otto C. M.: Clinical trials in spontaneous disease in dogs: a new paradigm for investigations of sepsis. J. Vet. Emerg. Crit. Care 2007, 17, 359-367, doi: 10.1111/j.1476-4431.2007.00249.x.

23. Plavec T., Celinsek B., Dolinar K., Pecar J., Nemec A., Butinar J.: Haemostasis impairment in bitches with pyometra. Acta Vet. (Beograd) 2006, 56, 529-540, doi: 10.2298/AVB0606529P.

24. Radwińska J., Domosławska A., Pomianowski A., Żarczyńska K., Jurczak A.: Implications of blood coagulation and fibrinolytic disorders in severe endometritis-pyometra complex in bitches. Bull Vet. Inst. Pulawy 2012, 56, 293-297, doi: 10.2478/v10213-012-0053-x
25. Schüttler J., Neumann S.: Interleukin-6 as a prognostic marker in dogs in an intensive care unit. Vet. Clin. Pathol. 2015, 44, 223-228, doi: 10.1111/ vcp. 12255 .

26. Träger K., Schütz C., Fischer G., Schröder J., Skrabal C., Liebold A., Reinelt H.: Cytokine reduction in the setting of an ARDS-associated inflammatory response with multiple organ failure. Case Rep. Crit. Care 2016, article id 9852073, doi:10.1155/2016/9852073.

27. Wang Y.-R., Tsai H.-I., Yu H.-P.: Organ dysfunction following trauma, shock and sepsis: An update. J. Anesth. Periop. Medi. 2015, 2, 36-44.

28. Werners A. H.: Treatment of endotoxemia and septicaemia in the equine patient. J. Vet. Pharmacol. Therap. 2016, 40, 1-15, doi: 10.1111/jvp.12329.

Corresponding author: Tuğba Seval Fatma Toydemir Karabulut, PhD, Istanbul University, Faculty of Veterinary Medicine, Department of Gynaecology and Obstetrics, Avcılar Campus, Istanbul, 34320, Turkey; e-mail: sevaltoydemir@yahoo.com 